factor in individual variability in genes, environment and lifestyle. She views it as a public-relations approach to managing research participants, offering what might seem innovative ideas to "make them want to comply". She delves, too, into complex cases such as that of Henrietta Lacks, whose cervical tumour was used to create the HeLa cell line without her consent (see Nature http://doi.org/kzq; 2013).

The book concludes with a vague proposal for a national commission to revisit the 1979 Belmont Report, the US federal report on ethical guidelines for research involving humans. Although Reardon's personal approach to the narrative is appealing, she only sparsely addresses the sociocultural and historical factors that shape genomics initiatives, and largely leaves out any analysis of the national policy frameworks that govern them. Her frequent reliance on political theory, particularly the works of Hannah Arendt, could also render the book inaccessible to a wider audience.

Reardon's underlying message is one of disappointment. She believes that genomics has enormous beneficial potential, but sees the human genome as a currency that so far has been deprived of value because, she alleges, of a lack of medical breakthroughs resulting from it. This is the major shortcoming of the book. As a storyteller, Reardon neglects narratives in which the value and transformative power of genetic discoveries have already accrued.

We don't hear of successful screening programmes for newborns, or emerging gene or cancer therapies such as those for spinal muscular atrophy or Duchenne muscular dystrophy, sickle-cell disease or leukaemia. We don't hear about initiatives that have already had an immense impact in the diagnosis or treatment of rare and intractable conditions - such as those for lysosomal-storage disorders or congenital myasthenic syndrome. Also absent are voices of people who are affected by genetic disorders, or who work at the interface of clinical care and research, where the meaning of the human genome is continuously emerging. In my view, had we heard from these actors, the answer to Reardon's core question - what is the value of the human genome? - would have been powerful and unequivocal. The human genome has an ineffable value.

Rosario Isasi is an assistant professor at the Department of Human Genetics, University of Miami Miller School of Medicine, Florida, USA.

e-mail:risasi@miami.edu

\title{
ECONOMICS
}

\section{How science got a golden ticket}

\section{Ehsan Masood hails an account of the mixed implications of governments valuing research as an investment.}

A ny researcher whose eyes glaze over at the phrase 'national accounting' should heed this tale. In the years since the financial crisis of 2008, Britain's science budget has been protected. While libraries shut, children's services shrank and nurses and teachers saw real wages fall, science spending has held steady. Why? Because successive finance ministers have been persuaded that cutting science, unlike cuts to other forms of public spending, would jeopardize the nation's future economic growth.

Notwithstanding the contested ethics for such a choice, chancellor George Osborne, one of these ministers, was able to protect science spending partly because of a seemingly arcane rule change by the UN Statistical Commission, implemented in Britain in 2014. Research and development had been recategorized as an investment rather than a cost, gifting science the golden ticket of future budget increases.

This is one tale told in Capitalism Without Capital. Economist Jonathan Haskel and UK government adviser Stian Westlake describe in an entertaining and engaging way why governments need to count innovation as an engine of profit. The authors also make

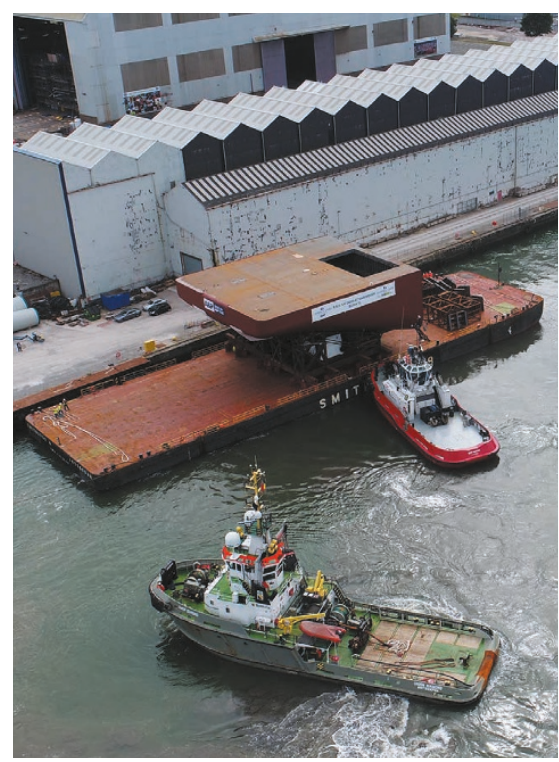

Construction of a new polar research vessel

funded by the UK government.

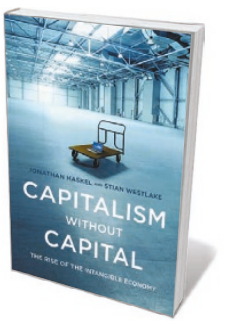

Capitalism Without Capital: The Rise of the Intangible Economy JONATHAN HASKEL \& STIAN WESTLAKE Princeton University Press: 2017. because much twentieth-century economic activity pivoted on industrial manufactured goods such as processed food, aircraft, cars, pharmaceuticals and weapons, all of which could be bought and sold for a price.

But the companies that made these goods - the Krafts, Fords and Raytheons - have since been joined by the likes of Amazon, Airbnb and Uber. And these 'new economy' companies have astronomical valuations. The problem is that national statistical offices from Chile to China have yet to agree on how all that these firms do should be reflected in gross domestic product, or GDP.

There are several reasons why this absence of what Haskel and Westlake call "intangibles" matters. Politicians, the markets and the media obsess about GDP figures. Political careers can rise or fall in tandem with them. Moreover, across the United States and Europe, and especially after the crash, the rate of GDP growth has been underwhelming; between 2010 and 2016, US GDP, for instance, rose by just $2.1 \%$ per year. If the figures are failing to account for one of the richest and fastest-growing economic sectors, then it is probable that the rate of economic growth is being underestimated. That alone is likely to be an incentive for governments to accelerate incorporation of intangibles into GDP.

Some intangibles, however, face bigger battles than others before they are likely to find a home in the GDP tent. Published 
valuations of the percentage of GDP accounted for by the 'domestic' economy - unpaid caring, cooking and cleaning in the home - range from $26 \%$ (estimated by the US Bureau of Economic Analysis) to $50 \%$. Yet GDP largely ignores this form of labour, along with women's central role in it.

That omission has not been lost on a number of organizations. The International Association for Feminist Economics, the Caring Economy Campaign and the Institute for Women's Policy Research, for instance, are working to end inequality and misogyny in economics. It is also true that male authors in this field (myself included) haven't covered this in the detail it deserves. In October, more than 1,000 economists signed a petition urging the American Economic Association to tackle misogyny. There are issues of methodology to resolve, but the principle of including household labour in the nation's books is unanswerable.

Comparatively more work has been done in valuing the cost of environmental degradation as a loss of 'natural capital'. In 2011, monetary values of natural capital and ecosystem services were conservatively estimated to be at least equal to GDP and possibly worth twice as much (see go.nature.com/2h0aro6 and R. Costanza et al. Glob. Environ. Change 26, 152-158; 2014). Yet this does not get a mention in Capitalism Without Capital. Biodiversity and ecosystem processes still languish outside GDP's remit, although as much as a decade ago, researchers Niu Wenyuan and Wang Jinnan came close to persuading China's leadership to create a green GDP.

When it comes to valuing research and development, Haskel and Westlake make a sobering observation. Now that science is an investment, its funders will expect it to behave as such. That means that there will be extra strain on the principle by which politicians don't interfere in the setting of academic research priorities - known in Britain as the Haldane principle, after First World War minister and troubleshooter Richard Burdon Haldane. The era of scientists being left to run their own show may be drawing to a close if science is expected to make economic returns. You have been warned.

Ehsan Masood is a Knight Science Journalism Fellow at the Massachusetts Institute of Technology in Cambridge. His latest book is The Great Invention: The Story of GDP and the Making and Unmaking of the Modern World. e-mail:emasood@mit.edu

\section{COMPUTER SCIENCE}

\section{Visionary of virtual reality}

\section{Aldo Faisal explores the immersive journey of technology pioneer Jaron Lanier.}

$\mathrm{V}$ irtual reality (VR) and its child, augmented reality, have long exerted a pull on the collective imagination. The ability to 'paint' $3 \mathrm{D}$, interactive, computer-generated worlds believably is hugely reliant on the technology's capability to embody a user's perception. Actions such as turning the head or standing up in the virtual world must precisely mimic the visual and auditory changes experienced in the real world. Now, VR pioneer Jaron Lanier recounts his part in the evolution of this extraordinary technology in Dawn of the New Everything.

Although concrete ideas about VR from the likes of computer artists Ivan Sutherland and Myron Krueger have been around since the 1960s, the technology began to take off only around two decades later. In 1984, Lanier and Thomas Zimmerman were researchers at computer-game company Atari when it shut its labs. The two set up VPL Research in a corner of Lanier's house in California's San Francisco Bay Area, creating an idea pool that invented the

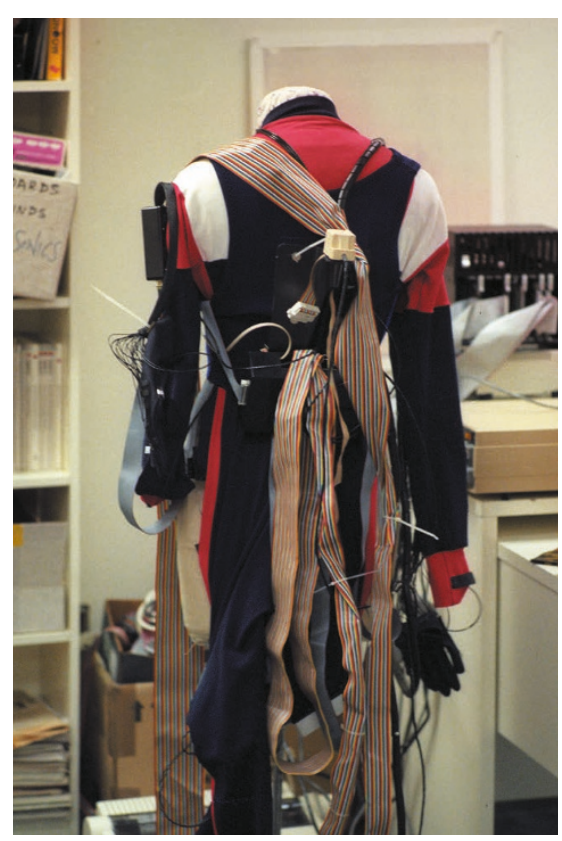

An early datasuit from Jaron Lanier's virtual-reality lab in 1989.

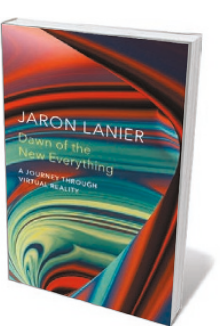

Dawn of the New Everything: A

Journey Through Virtual Reality

JARON LANIER

Bodley Head: 2017

Bodley Head: 2017. Lanier is also credited for the term virtua reality, later popularized by the influential 1992 technothriller film The Lawnmower Man. In it, a Lanier-like researcher played by Pierce Brosnan saves the day in 'cyberspace' (a coinage of science-fiction writer William Gibson), or networked VR. Lanier beautifully describes his fascination with VR as the technology that "highlights the existence of your subjective experience. It proves you are real."

Yet by the 1990s, that first wave of VR was already fizzling out. Targeted users failed to take to a technology that was costly, heavy and offered poor visual immersion. Computers needed to speed up considerably to allow head movements to be rendered fast enough in the 3D virtual world (a humancomputer loop that took longer than a few dozen milliseconds was notorious for causing VR 'seasickness'). By the 2010s, well-funded start-up companies including Oculus of Menlo Park, California, had developed faster graphics, lower-cost motion tracking and flat-panel displays that enabled a VR renaissance. That has been largely facilitated by the capabilities of current smartphone platforms, which act as lightweight, low-power, high-resolution screens.

Now, VR applications span science and society, from clinical rehabilitation treatments that enable people missing a limb to 'feel' it, to immersive journalism that can transport readers to a refugee camp (see go.nature.com/2yobrnc). 